of modern scientists on the issues of designing, modeling, models of various pedagogical processes is covered. In addition, a detailed description of its structural component components (social order, purpose and objectives, methodological, theoretical, practical, effective and corrective components) is presented, as well as a condition of sufficient generalization of the studied substantive and structural and procedural components by which it can be fulfilled tested and implemented in the real educational process of pedagogical institutions of higher education.

The basic stages of the process of system modeling (understanding and defining the functions of the simulated object; construction of the maximum functional system of the through components of the structure of the investigated object; establishing functional, logical, technological, semantic and other types of relationships between the components of the model; study the dynamics of the studied object, the accumulation of information about the object of study using theoretical and empirical methods of research).

The concept of creativity of future teachers of mathematics is considered, which in the framework of our research is understood as a set of equal independent component components (motivational, cognitive, activity, reflexive), contributing to the active creative activity of the students of higher education, which is aimed at solving educational model, developed development of creativity of future mathematics teachers in the process of professional training, primarily reflects the results of theoretical search (substantiated tasks, methodological odes, principles, factors, pedagogical conditions, stages, structural components, criteria, indicators etc.) for Marine appropriate system.

Key words: modeling, model, system, creativity, development of creativity of future educators, applicants for higher education, pedagogical university.

\title{
ВИЗНАЧЕННЯ СУТНОСТІ ПОНЯТТЯ «ПІСЛЯДИПЛОМНА ОСВІТА КЕРІВНИКІВ ЗАКЛАДІВ ЗАГАЯЬНОЇ СЕРЕДНЬОЇ ОСВІТИ УКРАЇНИ»
}

У статті розглянуто зміст понять «освіта», «освіта дорослих», «післядипломна освіта», «керівник», «заклад освіти»; здійснено огляд ключових концепцій вітчизняних, законодавчих визначень стосовно трактувань та структури зазначених понять. На основі логіко-структурного аналізу дослідження встановлено загальні явища та особливості, що стосуються післядипломної освіти керівних педагогічних кадрів. Виявлено, що післядипломна освіта керівників закладів освіти має системний характер та спрямована на вдосконалення вже набутого педагогічного та управлінського досвіду впродовж життя тапедагогічної діяльності, які $е$ свідченням становлення керівника закладу освіти. Управлінські компетентності керівників закладів освіти, що удосконалюються та формуються в процесі післядипломної освіти, залежать не тільки від попередньо набутих знань, умінь та навичок, а також від наповнення освітнього середовища навчальними дисциплінами з високим рівнем науковості. Проаналізовано базові категорії поняття, закцентовано на близькості сутності понять «освіта» та «післядипломна освіта»; з'ясовано сутність поняття «керівник» та виокремлено його особливості в контексті поняття «керівник закладу освіти»; опрацьвовано праці вітчизняних науковиів В. Андрущенко, О. Аніщенко, І. Жорової, А. Кисіль, Є. Коренева, В. Кременя, А. Аук'янової, І. Передборської, 
В. Примакової, В. Сластеніна щодо сутності та структури даних категорій. На основі аналізу базових понять, які наводихи вищезазначені науковці, запропоновано визначення поняття «післядипломна освіта керівників закладів загальної середньої освіти» в системі неперервної освіти педагогічних кадрів.

Ключові слова: освіта, післядипломна освіта, освіта дорослих, керівник, заклад загальної середньої освіти,

Постановка проблеми. Глобалізація та євроінтеграція як процеси спричинили виникнення великої кількості освітніх педагогічних концепцій, спрямованих на відшукування нових орієнтирів у сучасній освіті. На сучасному етапі розвитку педагогічної науки увагу зосереджено на пошуку концепції інноваційного педагогічного менеджменту, складовими якого є використання ефективних методів та прийомів управління педагогічними колективами, що має забезпечити ефективну взаємодію між учасниками педагогічного процесу.

У цьому контексті неможливо оминути необхідність неперервної освіти саме керівників закладів загальної середньої освіти України, оскільки ці педагогічні кадри мають бути справжніми лідерами в педагогічному колективі та забезпечувати якісну здагоджену його роботу, здійснювати ефективну організацію освітнього процесу в умовах реформування системи освіти.

На сьогодні процес організації постійного підвищення квадіфікації керівних педагогічних кадрів є найбільш гострим та відповідає сучасним тенденціям до надання якісної освіти учням закладів загадьної середньої освіти, що потребує пошуку оптимальних рішень в організації процесу післядипдомної освіти та підвищення кваліфікації керівників закладів загальної середньої освіти України.

Післядипломна освіта має базуватись на принципах науковості, систематичності й послідовності підготовки, поєднанні наукової теорії та практики. Теоретичні психолого-педагогічні знання, а також знання 3 менеджменту освіти мають стати основою сучасної продуктивної діяльності керівників закладів освіти та забезпечити їхній професійний розвиток.

У зв'язку 3 цим актуальним є питання дослідження сучасного змісту, що вкладається в поняття післядипломної освіти керівників закладів освіти.

Аналіз досліджень і публікацій, дозволяе зробити висновки, що педагогічною наукою накопичено значний позитивний досвід у галузі підвищення кваліфікації керівних педагогічних кадрів та їхньої післядипломної освіти. Зокрема, визначеній проблематиці присвячені роботи Є. Березняка, Б. Кобзаря, С. Ситар, В. Сухомлинського, М. Черпінського. Проблеми розвитку післядипломної освіти педагогічних кадрів досліджували Н. Волкова, І. Жорова, А. Зубко, С. Крисюк, А. Кузьмінський, В. Примакова та ін. Попри значний інтерес педагогічної науки до питань післядипломної освіти педагогічних кадрів, малодослідженим залишається поняття, саме «післядипломної освіти керівників закладів загальної середньої освіти».

Мета статті полягає в дослідженні наукових джерел та визначенні базових та ключових елементів понятійно-категорійного поля, що розкривають зміст поняття післядипломної освіти керівників закладів загальної середньої освіти України та їі роль у національній системі освіти.

Виклад основного матеріалу. Проаналізувавши джерельну базу, що складається 3 наукових, літературних та енциклопедичних джерел та провівши їх грунтовний аналіз 3 проблематики дослідження, стає зрозумілим, що «післядипдомна освіта керівника закладу загальної середньої освіти» є поєднанням споріднених понять «освіта», «освіта дорослих», «післядипломна освіта», а також «керівник» та «заклад середньої освіти», «керівник закладу освіти», а тому вважаємо за доцільне зупинити увагу саме на їхньому аналізі. 
Зміст поняття «освіта» історично трансформувався на певних етапах розвитку педагогічної науки, відображаючи концептуальні підходи до освітнього процесу. А отже, приступаючи до аналізу поняття «освіта», доцільно розглянути наявні формулювання його визначення та виділити їхні основні типи.

Освіта є одним 3 найстаріших соціальних явищ, що покликане передавати набутий досвід прийдешнім покодінням. На сьогодні освіта $є$ широковживаним та багатоплановим поняттям, його визначенню присвячено велику кількість наукових праць, зокрема В. Андрущенко та І. Передборська визначили, що «освіта» (рос. «образование»; англ. - «education»; нім. - «bildung»; грецьк. - «раideia») е суспільний процес (діяльність, інституція) розвитку й саморозвитку особистості, пов'язаний 3 оволодінням соціально значущим досвідом, утіленим у знаннях, уміннях, навичках творчої діяльності, чуттево-ціннісних формах духовно-практичного освоєння світу» $[9$, с. 8].

Розглядаючи поняття «освіта», В. Сластенін зазначає, що «під освітою розуміють єдиний процес фізичного і духовного становлення особи, процес соціалізації, свідомо орієнтований на деякі ідеальні образи, на історично зафіксовані в суспільній свідомості соціальні еталони (наприклад, спартанський воїн, доброчесний християнин, енергійний підприємець, гармонійно розвинена особа). У такому розумінні освіта виступає невід'ємною стороною життя усіх суспільств і всіх без винятку індивідів, тому вона є, передусім, соціальним явищем, що є цілеспрямованим процесом виховання і навчання в інтересах людини, суспільства і держави» [8, с. 55].

В. Кремень в «Енцикдопедії освіти» розгдядае поняття «освіта» як «цілеспрямовану пізнавальну діяльність людей з отримання знань, умінь та навичок або щодо їх удосконалення. Процес і результат засвоєння особистістю певної системи наукових знань, практичних умінь та навичок і пов'язаного з ними того чи іншого рівня розвитку іï розумово-пізнавальної і творчої діяльності, а також морально-естетичної культури, які у своїй сукупності визначають соціальне обличчя та індивідуальну своєрідність цієї особистості» [1, с. 614].

Отже, проаналізувавши визначення поняття «освіта» $1 ; 8 ; 9]$, можемо дійти висновку, що освіта як суспільний багатоаспектний процес набуття певної системи знань, умінь і навичок необхідних для успішної діяльності індивіда в певній галузі та є базовим і обов'язковим елементом для визначення та розкриття сутності поняття «післядипломної освіти керівника закладу освіти».

Таким чином, післядипломна освіта керівників закладів освіти є складовим елементом системи освіти, що спрямований на вдосконалення знань, умінь, навичок та досвіду набутого на попередніх етапах системи освіти.

Згідно з Законом України «Про освіту», післядипломна освіта передбачає набуття нових та вдосконалення раніше набутих компетентностей на основі здобутої вищої, професійної (професійно-технічної) або фахової передвищої освіти та практичного досвіду [7].

Післядипломна освіта включае перепідготовку - освіту дорослих, спрямовану на професійне навчання з метою оволодіння іншою (іншими) професією (професіями); підвищення кваліфікації - набуття особою нових та/або вдосконалення раніше набутих компетентностей у межах професійної діяльності або галузі знань [там само].

Детальним та широким вивченням питань освіти дорослих займається андрагогіка, що допомагає виділити та сформудювати складові та основні цілі освіти дорослих та надає їі поняття.

У короткому термінологічному словнику Д. Аук'янова, О. Аніщенко надають таке визначення: «Освіта дорослих - цілеспрямований процес розвитку і виховання особистості шляхом реалізації освітніх програм і послуг, здійснення освітньоінформаційної діяльності в межах та поза межами загальної середньої, професійнотехнічної, вищої і післядипломної освіти (за В. Буренко)» [5, с. 64].

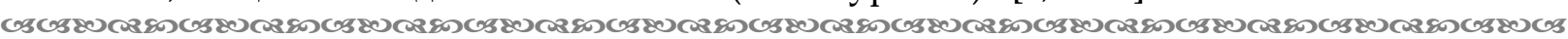


На думку І. Жорової, «післядипломна освіта» має розумітись «як галузь освіти фахівців, у середовищі якої відбувається їхній неперервний професійний розвиток відповідно до суспільних запитів, вимог державної освітньої подітики й індивідуальних освітніх потреб» $[2$, с. 13$]$.

В. Примакова вважає, що «післядипломна педагогічна освіта покликана забезпечувати неперервне професійне зростання, розвиток творчого потенціалу, професійне й особистісне вдосконалення та самореалізацію педагога, отже професіоналізацію, що трактується, як опанування професією» [6, с. 17].

Не зважаючи на різноманітні трактування поняття післядипломна освіта $[2 ; 5 ; 6 ; 7]$, вони мають взаємодоповнювальний характер та спільну рису, на якій збігаються думки вчених про вдосконалення і поглиблення професійних якостей та розвиток вже набутих компетентностей.

Післядипломна освіта керівника закладу загальної середньої освіти має наповнюватись відповідним змістом навчальних дисциплін високого рівня науковості, який відображатиме найсучасніші надбання не тільки психодого-педагогічної науки, а й ефективного менеджменту освіти.

Роль сучасного професійного менеджера закладу освіти має відігравати його керівник. У цьому аспекті необхідно розглянути сутність поняття «керівник», яке є одним з найпоширеніших сьогодні.

Є. Коренєв розглядає термін «керівник» дослівно так: «...управляти, направляти й бути на чолі чого-небудь» [4, с. 183].

У «Юридичній енциклопедії» поняття «керівник» визначено, як «посадова особа, яку наділено адміністративною владою щодо очодюваного нею колективу і яка здійснюе внутріорганізаційне управління ним» [10].

Керівник - особа, яка очолюе колектив і використовуе надану йому владу для впливу на поведінку дюдей, що в ньому працюють. Особа, яка виконуе функції керівника, має різні назви в залежності від сфери, у якій вона працює. А. Кисіль зазначає той факт, що керівників називають «адміністраторами», «менеджерам» або «організаторами роботи керованого ними колективу» [3, с. 34].

У національному законодавстві «керівник закладу освіти визначається як особа, що здійснюе безпосередне управління закладом і несе відповідальність за освітню, фінансово-господарську та іншу діяльність закладу освіти» [7]. Законом України «Про освіту» (ст. 26) керівника закладу освіти наділено низкою адміністративних повноважень.

Перелічені нами переважно юридичні трактування поняття «керівник» не вичерпують його змісту, проте вони важдиві для розкриття поняття «керівник закладу освіти».

У Законі України «Про освіту» визначено, що «заклад освіти - юридична особа публічного чи приватного права, основним видом діяльності якої є освітня діяльність» [там само].

Таким чином, аналіз літературних джерел [3; 4; 7; 10], у яких наведено трактування поняття «керівник» у сподученні 3 законодавчо закріпленими повноваженнями керівника закладу освіти та визначенням поняття «заклад освіти», дає змогу надати власне бачення визначення терміну «керівник закладу освіти». Це посадова особа закладу освіти, наділена владними адміністративними повноваженнями, на яку покладено управлінську, організаційну, представницьку, контрольну та інші функції зі створення належних умов освітньої діяльності педагогічного колективу, забезпечення освітнього процесу з надання якісної освіти відповідно до визначених стандартів та програм.

Висновки. Аналіз публікацій та різноманітних джерел дає нам змогу констатувати, що педагогічною наукою накопичено значний позитивний досвід у розкритті окремих понять «освіта», «пісдядипдомна освіта», «керівник», «заклад

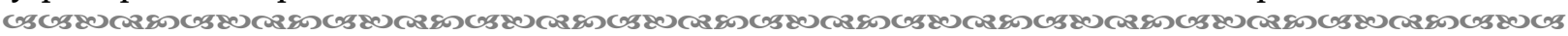


освіти». Але дослідження науковців наразі не дають одностайно чіткого трактування об’єднаного поняття «післядипломна освіта керівників закладів загальної середньої освіти України».

Післядипломну освіту керівника закладу освіти ми вважаємо окремим напрямом неперервної освіти педагогічного працівника, що базується на вже набутих знаннях та досвіді, у процесі якого удосконалюються менеджерські компетентності зі створення організаційно-педагогічних умов 3 необхідного супроводу освітнього процесу в закладі освіті.

Кожне із досліджених понять має як загальні властивості, так і специфічні якості, які можна застосувати до категорії керівників закладів освіти. Аналізуючи окремі наукові поняття, можемо дійти висновку, що в них описані їхні загальні властивості, що зумовдюе необхідність конкретизації на основі попереднього позитивного педагогічного досвіду теоретичних положень та базису поняття «післядипломна освіта керівників закладів освіти», що зумовлюе перспективу подальших наукових досліджень цього освітнього процесу як в історичній ретроспективі, так і в руслі реформування системи освіти.

\section{Список використаних джерел:}

1. Енциклопедія освіти / Акад. пед. наук України, головний ред. В. Г. Кремень, Київ : Юрінком Інтер, 2008. 1040 c.

2. Жорова І. Я. Теорія і практика розвитку професіоналізму вчителів природничих дисциплін у системі післядипломної освіти України (1940-і pp. XX - початок XXI ст.) : монографія. Херсон : КВНЗ «Херсонська академія неперервної освіти», 2016. 447 с.

3. Кисіль А. Є. Керівник підприємства: компетенція та адміністративна відповідальність. Київ: «Наукова думка», 1998. 82 с.

4. Коренев Э.Н. Анализ современного состояния системы корпоративного управления в Украине. Економіка: Менеджмент. Підириємництво: зб. наук. праць. 2001. № 4. С. 180-190.

5. Лук'янова Л. Б., Аніщенко О. В. Освіта дорослих: короткий термінологічний словник / авт.-упор. Аук'янова А. Б., Аніщенко О. В. Київ; Ніжин : Видавець ПП Лисенко М.М., 2014. $108 \mathrm{c}$.

6. Примакова В. В. Післядипломна освіта вчителів початкових класів в Україні (середина XIX початок XXI століття) : монографія. Херсон : КВНЗ «Херсонська академія неперервної освіти», 2014. 336 с.

7. Про освіту: Закон України від 05.09.2017 p. № 2145-VIII. URL : https://zakon.rada.gov.ua/laws/show/2145-19\#n270.

8. Сластенин В. А. и др. Педагогика : учеб. пособие дия студ. высш. пед. учеб. заведений / В. А. Сластенин, И. Ф. Исаев, Е. Н. Шиянов; под ред. В. А. Сластенина. Москва: Издательский центр «Академия», 2013. 576 с.

9. Філософія освіти : навчальний посібник / за заг. ред. В. Андрущенка, І. Передборської. Київ : Вид-во НПУ імені М. П. Драгоманова, 2009. 329 с.

10. Юридична енциклопедія : в 6 т. / Інститут держави і права ім. В. М. Корецького НАН України; редкол. : Ю. С. Шемшученко (голова) та ін. Київ : Вид-во «Українська енциклопедія» ім. М. П. Бажана. Т. 3. К.-М., 2001. 792 с.

\section{References:}

1. Kremen, V. G. (Ed.). (2008). Entsyklopediya osvity [Encyclopedia of education]. Kyiv: Yurinkom Inter [in Ukrainian].

2. Zhorova, I. Ya. (2016). Teoriya i praktyka rozvytku profesionalizmu vchyteliv pryrodnychykh dystsyplin u systemi pislyadyplomnoyi osvity Ukrayiny (1940-i rr. XX st - pochatok XXI stolittya) [Theory and practice of professional development of teachers of natural sciences in the system of postgraduate education of Ukraine (40-s of the XX century - the beginning of the XXI century)]. Kherson: KVNZ "Khersonska akademiia neperervnoi osvity" [in Ukrainian].

3. Kisil, L. (1998). Kerivnyk pidpryyemstva: kompetentsiya ta administratyvna vidpovidalnist [Head of the enterprise: competence and administrative responsibility]. Kyiv: "Naukova dumka" [in Ukrainian]. 
4. Korenev, E. N. (2001). Analyz sovremennoho sostoyanyya systemy korporatyvnoho upravlenyya $\mathrm{v}$ Ukrayne [Analysis of the current state of the corporate governance system in Ukraine]. Ekonomika: Menedzhment. Pidpryyemnytstvo, 4, 180-190 [in Ukrainian].

5. Lukyanova, L. B., \& Anishchenko, O. V. (2014). Osvita doroslykh: korotkyy terminolohichnyy slownyk [Adult education: a short terminological dictionary]. Kyiv; Nizhyn: Vydavets' PP Lysenko M. M. [in Ukrainian].

6. Primakova, V. V. (2014). Pislyadyplomna osvita vchyteliv pochatkovykh klasiv v Ukrayini (seredyna XX pochatok XXI stolittya) [Postgraduate education of primary school teachers in Ukraine (mid-XIX early XXI century)]. Kherson: KVNZ "Khersonska akademiia neperervnoi osvity" [in Ukrainian].

7. Law of Ukraine on education from September 05 2017, No 2145 - VIII. Retrieved from https://zakon.rada.gov.ua/laws/show/2145-19 [in Ukrainian].

8. Slastenin, V., Isaev, I., \& Shiyanov, E. (2013). Pedagogika [Pedagogy]. Moscow: Izdatel'skiy tsentr "Akademiya" [in Russian].

9. Andrushchenko, V. \& Predborska, I. (Ed.). (2009). Filosofiya osvity [Philosophy of education]. Kyiv: Vyd-vo NPU imeni M. P. Drahomanova [in Ukrainian].

10. Shemshuchenko, Yu. (Ed.). (2001). Yurydychna entsyklopediya [Legal encyclopedia]. (Vols. 3). Kyiv: Vyd-vo "Ukrayinska entsyklopediya" im. M. P. Bazhana [in Ukrainian].

Vyshnevska Ya. A., orcid.org/0000-0003-3703-4119

\section{DEFINITION OF THE ESSENCE OF THE CONCEPT “POSTGRADUATE EDUCATION OF MANAGERS OF GENERAL SECONDARY EDUCATIONAL INSTITUTIONS OF UKRAINE"}

The article considers the content of the concepts "education", "adult education", "postgraduate education", "manager", "educational institution"; the review of key concepts of Ukrainian legislative definitions concerning interpretations and structure of the specified concepts is carried out. On the basis of logical-structural analysis in this study the general phenomena and features concerning postgraduate education of managerial pedagogical personnel are established and own interpretation of definition of concept "postgraduate education of managers of general secondary educational institutions" in system of continuous education of pedagogical staff is offered. It is highlighted that postgraduate education of managers of general secondary educational institutions has a systemic character and is aimed at improving pedagogical and managerial experience already acquired during life and pedagogical activity, which is evidence of the formation of managerial competencies of the head of educational institution. Works of Ukrainian scientists, in particular V. Andrushchenko, O. Anishchenko, I. Zhorova, L. Kysil, E. Koreneva, V. Kremen, L. Lukyanova, I. Peredborska, $V$. Primakova, V. Slastenin on the essence and structure of these categories are analyzed. As a result of the analysis of the concepts "postgraduate education" and "adult education" proposed by scholars, it was found that the development of managerial competencies and professionalism of the head of the educational institution, improved and formed in the process of postgraduate education depends not only on previously acquired knowledge and skills, as well as from filling the educational environment with academic disciplines with a high level of scientificity. The basic categories of concepts are analyzed and attention is focused on the closeness of the essence of such concepts as "education" and "postgraduate education"; the essence of the concept of "manager" is clarified and its features in the context of the concept of "head of an educational institution" are singled out.

Key words: education, postgraduate education, adult education, manager, general secondary educational institution, head of general secondary educational institution. 